\title{
Measuring Green Banking Practices on Bank's Environmental Performance: Empirical Evidence from Kathmandu valley
}

\author{
Nischal Risal, MPhil \\ Assistant Professor \\ nischalrisal@gmail.com \\ Nepal Commerce Campus, TU \\ Sanjeev Kumar Joshi \\ Freelance Researcher \\ joshisanjub@gmail.com
}

\begin{abstract}
The research paper aims to analyze the impact of green banking practices on bank's environmental performance in Nepal. The casual relational research design has been adopted in the study. The simple and stepwise multiple regression analysis have been performed to accomplish the objective of the research. The research paper follows cross-sectional qualitative research with descriptive outcome. The Chronbach's Alpha has been used to analyze the reliability of instruments and data. The 189 samples have been collected from the banks using convenience sampling method. The SPSS software has been used to tabulate and analyze the data. The research paper concluded the energy efficient equipments and green policy posed the significant impact on bank's environmental performance; green loan and green project as not. Similarly, the environmental training contributed mild to bank's environmental performance. The findings of the paper suggested the role of banks and government in encouraging environmentally sustainable technologies as highly important for increasing bank's reputation and awareness among customers.
\end{abstract}

Keywords; Environmental Training, Energy Efficient Equipments, Green Policy, Green Loan, Green Project

\section{Introduction}

During the last few decades, shifting of societal concern towards environmentally 
friendly practices has been the prime concern of governments, policy makers, business firms and the public justified through a number of dialogues on issues pertaining to environmental protection and 'climate change. Couples of years back, issues pertaining to environment were barely relevant to financial sectors (Shaumya \& Anton Arulrajah, 2017). However, at the current times banks have been viewed as contributing to pollution through their operations and increasing emission of carbon dioxide via use of airconditions, lights, electronic and fuel equipment, financing environment polluting projects. Such problem impacts directly on the supply chain disruption and indirectly on the health leading to loss of man-hours and efficiency (Koiry, Saha, Farid, Sultana, \& Haque, 2017). Therefore, implementation of green banking has become the need of the hour, promoting environment-friendly practices and reducing carbon footprints establishing the internal banking processes, physical infrastructure and information technology effective towards the environment.

Instruments such as using online banking, opening up accounts at online banks, paying bills online (Ritu, 2014), offering credit cards (Tandon \& Setia, 2017), they can play instrumental role in this regard. Consequently, achieving better performance in terms of environmental indicators is crucial. Environmental performance can be evaluated by set of indicators as low environmental releases, prevention of pollution, waste minimization and recycling activities (Lober, 1996). The year 2009 was marked by coming of the first green bank based in Mt. Dora, Florida, United States (Jayabal \& Soundarya, 2016). However, Laxmi Bank was the first bank initiating green banking strategies in Nepal (Mehta \& Sharma, 2016) followed by Standard Chartered Bank. Laxmi bank focuses on digitization basically through two core services namely mobile money service and internet banking (Lama, 2018). Introducing such initiatives avoids customer-counter delay and provides access to easy finance; added Lama. Amongst others, Clean Energy Development Bank and Sanima Bank seems encouraging hydropower investment, solar energy development funds; Standard Chartered Bank Nepal (SCBN) has been able to achieve reduction in consumption of diesel, electricity, and water by $2 \%, 12 \%$, and $13 \%$ respectively in 2011 vis-à-vis 2010 (Standard Chartered Bank, n.d.).

\section{Objective}

To analyze the impact of green banking practices on bank's environmental performance in Kathmandu, Nepal.

\section{Hypotheses}

H1: There is significant relation between green banking practices and bank's environmental performance in Nepal.

H2: There is significant relation between green policy and bank's environmental performance in Nepal.

H3: There is significant relation between environmental training and bank's environmental performance in Nepal.

H4: There is significant relation between energy efficient equipment's and bank's environmental performance in Nepal. 
H5: There is significant relation between green loan and bank's environmental performance in Nepal.

H6: There is significant relation between green project and bank's environmental performance in Nepal.

\section{Literature Review}

Conceptual Framework

The research paper has attempted to deal with four dimensions namely employee related practices, daily operation related practices, customer related practices and bank's policy related practices constituting five independent variables along with their relationship with the dependent variables. Bank's environmental performance being the dependent variable whereas environmental training, energy efficient equipment, green loan, green project, and green policy being the independent variable.

Figure 1

Schematic Diagram of Conceptual Framework (Shaumya \& Anton Arulrajah, 2017)

Independent Variable

Dependent Variable

Employee Related Practices

- Environmental training

Daily Operation Practices

- Energy efficient Equipment

Customer Related Practices

- Green Loan

- Green Project

Bank's Policy Related Practice

- Green Policy

\section{Green Banking Strategies}

According to (Jha \& Bhome, 2013) the green banking strategies for sustainable developments were mentioned below: 


\section{Going Online}

Online initiatives like e-banking, using less paper, less energy, and less expenditure on projects assists in power saving and resource preservation.

\section{Using Green Checking Accounts}

Its usage rate can be increased by providing higher rate of interest, waiver of fees, and the like.

Green Loans for Home Improvements

Providing low or differential interest loans to customers for purchasing solar equipment's.

\section{Power Saving Equipment}

Power efficiency may be the introduction of solar-powered ATM, replacing General Lamp Shape (GLS) or incandescent bulbs with LED bulbs.

\section{Saving Papers}

Banks should buy recycled paper products with the highest post-consumer waste content possible.

\section{Green Credit Cards}

Using green credit cards can motivate non-profit NGO as the bank will contribute fund to them on account of environment conservation. Furthermore, the schematic representation of factors influencing the green banking practices as per (Jovonk, 1998) is mentioned below:

\section{Green product and services}

Green product and services for bank refers to the product and services that helps in achieving resource utilization efficiency followed by improved financial performance of the bank.

\section{Green Strategies}

Eric G. Olson defines green strategy as complements the business, operations and asset strategies already understood and articulated by the enterprise that has a positive impact on the environment.

\section{Green Checking Accounts}

Using ATM to examine the accounts is referred as green checking account. 
Table 1

Summary of Literature Review

\begin{tabular}{|c|c|c|}
\hline Authors & Research Methodology & Major Findings \\
\hline $\begin{array}{l}\text { (Salvado, } \\
\text { Castro, Verde, \& } \\
\text { Lopez, 2013) }\end{array}$ & $\begin{array}{l}\text { Empirical study using } \\
\text { questionnaire design and } \\
\text { research resume. }\end{array}$ & $\begin{array}{l}\text { Environmentally proactive } \\
\text { strategies had promoted } \\
\text { ecological innovation and could } \\
\text { lead to competitive advantage. }\end{array}$ \\
\hline $\begin{array}{l}\text { (Jha \& Bhome, } \\
\text { 2013) }\end{array}$ & $\begin{array}{l}\text { Telephonic interaction and } \\
\text { personal interview including } \\
\text { structured questionnaire were } \\
\text { served with random method of } \\
\text { sample collection. }\end{array}$ & $\begin{array}{l}\text { Green banking practices was } \\
\text { a way of conducting business } \\
\text { along with considering the social } \\
\text { and environmental impacts on its } \\
\text { activities. }\end{array}$ \\
\hline $\begin{array}{l}\text { (Rajput, Arora, \& } \\
\text { Khanna, 2013) }\end{array}$ & $\begin{array}{l}\text { Empirical test was done using } \\
\text { data panel regression method } \\
\text { from } 1997 \text { to } 2013 \text {. }\end{array}$ & $\begin{array}{l}\text { Environmental performance } \\
\text { and financial performance were } \\
\text { positively related. }\end{array}$ \\
\hline (Gopi, 2016) & $\begin{array}{l}\text { Primary and secondary data } \\
\text { were collected via questionnaire, } \\
\text { interviews and facts presented } \\
\text { in the form of table, graph, } \\
\text { charts and pie diagram using } \\
\text { convenience sampling and } \\
\text { descriptive research design. }\end{array}$ & $\begin{array}{l}\text { Banks were indirectly } \\
\text { contributing to environment } \\
\text { degradation by financing projects } \\
\text { whose activities put negative } \\
\text { impact to the environment } \\
\text { were now encouraging projects } \\
\text { that shown its concern for } \\
\text { environment. }\end{array}$ \\
\hline (Aubhi, 2016) & $\begin{array}{l}\text { Qualitative research design } \\
\text { was employed. Secondary } \\
\text { source of data collected through } \\
\text { research papers, sustainability } \\
\text { reports of different banks and } \\
\text { environmental organizations. } \\
\text { Microsoft office package had } \\
\text { been used for summarized and } \\
\text { illustrated the collected data } \\
\text { systematically. }\end{array}$ & $\begin{array}{l}\text { Few commercial banks } \\
\text { were engaged in in-house } \\
\text { environmental management } \\
\text { and were contributing towards } \\
\text { environmental friendly finance } \\
\text { through their Green Energy } \\
\text { Loans. However, more scope to } \\
\text { contribute and made adequate } \\
\text { investment in generating } \\
\text { renewable energy did exists. }\end{array}$ \\
\hline $\begin{array}{l}\text { (Shaumya \& } \\
\text { Anton Arulrajah, } \\
\text { 2017) }\end{array}$ & $\begin{array}{l}\text { Univariate, bivariate and multi } \\
\text { variate analysis was done } \\
\text { among employee of commercial } \\
\text { banks using primary data using } \\
\text { disproportionate stratified } \\
\text { sampling survey method. }\end{array}$ & $\begin{array}{l}\text { Adopting green banking practices } \\
\text { ultimately resulted in saving the } \\
\text { environment and enhancing the } \\
\text { performance of the banks. }\end{array}$ \\
\hline $\begin{array}{l}\text { (Tandon \& Setia, } \\
\text { 2017) }\end{array}$ & $\begin{array}{l}\text { Primary and secondary data } \\
\text { had been used after conducting } \\
\text { pilot survey. Garrett's ranking } \\
\text { techniques was also used. }\end{array}$ & $\begin{array}{l}\text { Central bank and the government } \\
\text { should collectively play a } \\
\text { proactive role and formulate } \\
\text { green policy guidelines. }\end{array}$ \\
\hline
\end{tabular}




\section{Research Methodology}

The perceptions of the 189 commercial bankers were collected, that had included 25 pilot survey respondents working in Kathmandu valley. The convenience sampling method had been used. The casual relational research design had been adopted in the research. The 152 sets of questionnaires had been selected for further coding and analysis.

Table 2

Sample Banks

\begin{tabular}{|c|c|c|c|c|}
\hline S.N & Sample Banks & $\begin{array}{c}\text { Total No. } \\
\text { of Staff in } \\
\text { Sample Banks }\end{array}$ & $\begin{array}{c}\text { No. of } \\
\text { Questionnaire } \\
\text { Distributed }\end{array}$ & Remarks \\
\hline 1. & $\begin{array}{l}\text { Agricultural } \\
\text { Development Bank Ltd. }\end{array}$ & 200 & 33 & Government Bank \\
\hline 2. & NIC Asia Bank & 127 & 38 & Merged Bank \\
\hline 3. & Sanima Bank & 112 & 41 & $\begin{array}{l}\text { Encourage } \\
\text { green initiatives }\end{array}$ \\
\hline 4. & Laxmi Bank & 137 & 43 & $\begin{array}{l}\text { First bank to initiate } \\
\text { green banking practices }\end{array}$ \\
\hline 5. & Siddhartha Bank & 85 & 34 & Private Sector bank \\
\hline
\end{tabular}

The data were statistically analyzed using Statistical Package for Social Sciences Software (SPSS) version 20.0. The simple and stepwise multiple regression analysis were performed to accomplish the objective of the study. The research paper follows crosssectional qualitative research with descriptive outcome. Chronbach's Alpha was used to analyze the reliability of instruments and data.

Table 3

Regression Models

\begin{tabular}{ll}
\hline Model & Equation \\
\hline 1 & GB_BEP $=\beta_{0}+\beta_{1} E T+e$ \\
2 & GB_BEP $=\beta_{0}+\beta_{2} E E F+e$ \\
3 & GB_BEP $=\beta_{0}+\beta_{3} G P+e$ \\
4 & GB_BEP $=\beta_{0}+\beta_{4} G L+e$ \\
5 & GB_BEP $=\beta_{0}+\beta_{5} G P_{j}+e$ \\
6 & GB_BEP $=\beta_{0}+\beta_{1} E T+\beta_{3} G P+e$ \\
7 & GB_BEP $=\beta_{0}+\beta_{1} E T+\beta_{2} E E F+\beta_{3} G P+e$ \\
8 & GB_BEP $=\beta_{0}+\beta_{1} E T+\beta_{2} E E F+\beta_{3} G P+\beta_{4} G L+\beta_{5} G P_{j}+e$ \\
\hline Where $Y=$ Bank's Environmental Performance
\end{tabular}

Where $Y=$ Bank's Environmental Performance

$X_{1}=$ Environmental training

$X_{2}=$ Energy efficient equipment's

Journal of Business and Social Sciences (JBSS) 
$X_{3}=$ Green Policy

$X_{4}=$ Green Loan

$X_{5}=$ Green Project

$\beta_{0}=$ intercept of the regression and $\beta_{1,} \beta_{2}, \beta_{3} \beta_{4} \beta_{5}, \beta_{6}$ are the coefficient of regression

\section{Research Findings}

Correlation Analysis

The result shows, the Coefficient of correlation $(r)$ is 0.268 indicating mild positive correlation between green banking practices and bank's environmental performance with the level of significance at $0.001(p<0.05)$. Similarly, the Spearman's rho is 0.194 with the level of significance at $0.017(p<0.05)$ conclusive of the positive relation between green banking practices and bank's environmental performance.

Table 4

Correlation Matrix

\begin{tabular}{|c|c|c|c|}
\hline & & $\begin{array}{c}\text { Green Bank } \\
\text { BEP }\end{array}$ & $\begin{array}{c}\text { Green Banking } \\
\text { Practices }\end{array}$ \\
\hline \multirow{2}{*}{$\begin{array}{l}\text { Green Bank BEP* } \\
\text { *Bank's Environmental } \\
\text { Performance }\end{array}$} & Pearson Correlation & 1 & $.268^{\star \star}$ \\
\hline & Sig. (2-tailed) & & .001 \\
\hline \multirow{2}{*}{$\begin{array}{l}\text { Green Banking } \\
\text { Practices }\end{array}$} & Spearman's rho & $.194^{*}$ & 1 \\
\hline & Sig. (2-tailed) & .017 & \\
\hline
\end{tabular}

\section{Regression Analysis}

Coefficient of Green Banking Practices on Bank's Environmental Performance

The analysis revealed $\mathrm{R}$ square at 0.068 with level of significance level is $0.001(p<0.05)$ implying $6.8 \%$ of the variability in bank's environmental performance is accounted by green banking practices.

Table 5

Green Banking Practices on Bank's Environmental Performance

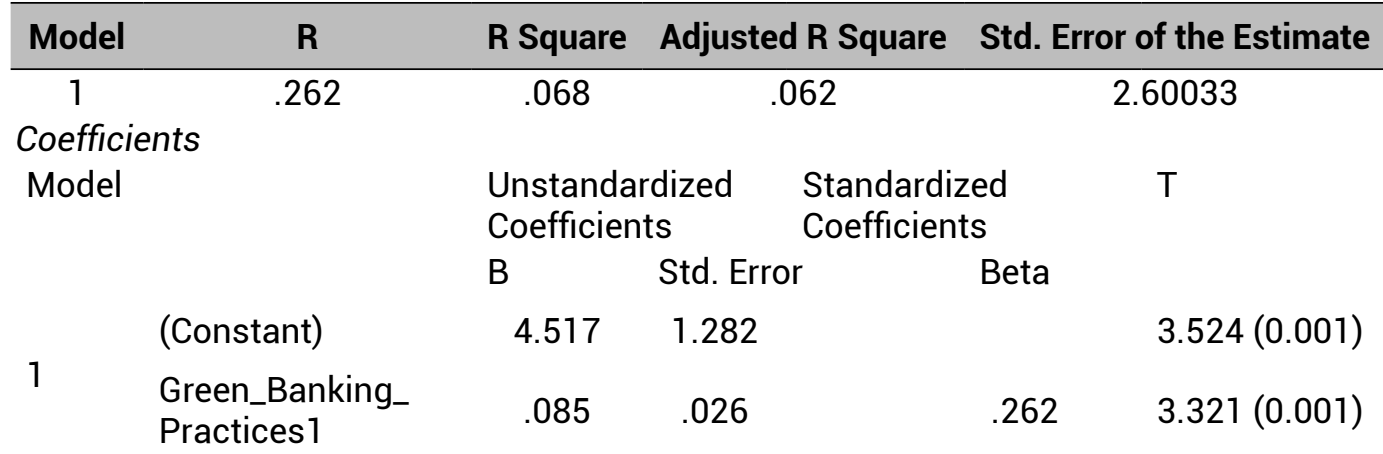


Predictors: (Constant), Green Banking Practices 1

Dependent Variable: Green Bank BEP

Simple Regression Analysis

The $9.8 \%$ of the variability in bank's environmental performance is accounted by green banking practices with level of significance for environmental training at 0.061 meaning, it is at the margin of statistical significance (Ogee, et al., 2015). Similarly, $\mathrm{P}<0.05$ for energy efficient equipments (0.009), green policy $(0.008)$ whereas $P>0.05$ for green loan (0.224) and green project (0.175) confirms green loan and green project has not significant influence on bank's environmental performance.

Table 6

Simple Regression Analysis

\begin{tabular}{lrrrrr}
\hline Model & $\mathbf{R}$ & & R Square & Adjusted Square & $\begin{array}{c}\text { R Std. Error of the } \\
\text { Estimate }\end{array}$ \\
1 & .312 & .098 & & .067 & 2.59423
\end{tabular}

Coefficients

\begin{tabular}{lcccccc}
\multicolumn{1}{c}{ Model } & \multicolumn{2}{c}{$\begin{array}{c}\text { Unstandardized } \\
\text { Coefficients }\end{array}$} & $\begin{array}{c}\text { Standardized } \\
\text { Coefficients }\end{array}$ & T & Sig. \\
& B & Std. Error & Beta & & \\
\hline (Constant) & 9.301 & 1.150 & & 8.090 & .000 \\
Env_Train1 & .160 & .085 & .151 & 1.887 & .061 \\
& Energy_Eff1 & .274 & .103 & .273 & 2.661 & .009 \\
Green_Policy1 & -.265 & .098 & -.269 & -2.707 & .008 \\
Green_Loan1 & -.122 & .100 & -.108 & -1.220 & .224 \\
Green_Project1 & -.141 & .103 & -.122 & -1.364 & .175
\end{tabular}

Dependent Variable: Green_Bank_BEP

The overall fitness of the model (F-statistics) has been reported at 11.029 with the level of significance at $1 \%$ as shown in the ANOVA table below.

Table 7

Analysis of Variance

\begin{tabular}{lllllll}
\hline & Model & Sum of Squares & Df & Mean Square & F & Sig. \\
\hline & Regression & 74.578 & 1 & 74.578 & 11.029 & .001 \\
1 & Residual & 1014.257 & 150 & 6.762 & & \\
& Total & 1088.836 & 151 & & & \\
\hline
\end{tabular}

Dependent Variable: Green_Bank_BEP

Predictors: (Constant), Green_Banking_Practices 1 
Stepwise Regression Analysis

Bank's Policy Related Practices (Green Policy and Bank's Environmental Performance)

The paper acknowledges $\mathrm{R}$ square at 0.018 implying $1.8 \%$ of the variability in bank's environmental performance is accounted by green banking practices with level of significance at 0.098 . Since, $p>0.05$, the null hypothesis is accepted.

Table 8

Bank's Policy Related Practices

\begin{tabular}{ccccc}
\hline Model & R & R Square & Adjusted R Square & Std. Error of the Estimate \\
\hline 1 & .135 & .018 & .012 & 2.66970 \\
\hline
\end{tabular}

Predictors: (Constant), Green_Policy 1

Dependent Variable: Green_Bank_BEP

Table 9

Analysis of Variance

\begin{tabular}{lllllcr}
\hline & Model & Sum of Squares & Df & Mean Square & F & Sig. \\
\hline & Regression & 19.744 & 1 & 19.744 & 2.770 & $.098^{b}$ \\
1 & Residual & 1069.091 & 150 & 7.127 & & \\
& Total & 1088.836 & 151 & & & \\
\hline
\end{tabular}

Dependent Variable: Green_Bank_BEP

Predictors: (Constant), Green_Policy 1

Bank's Policy and Employee Related Practices (Green Policy and Environmental Training)

Bank's Policy and Employee Related Practices

Table 10

\begin{tabular}{lcccc}
\hline Model & R & R Square & $\begin{array}{c}\text { Adjusted R } \\
\text { Square }\end{array}$ & Std. Error of the Estimate \\
\hline 1 & $.201^{\mathrm{a}}$ & .040 & .028 & 2.64797 \\
\hline
\end{tabular}

Predictors: (Constant), Env. Train 1, Green Policy1

Dependent Variable: Green Bank BEP

The paper reveals $R$ square at 0.04 with level of significance at $0.046(p<0.05)$ indicating $96 \%$ of variance of bank's environmental performance is affected by other variables leading to the rejection of null hypothesis. The fitness of the model (F-statics) is at 3.144 . 


\section{Table 11}

Analysis of Variance

\begin{tabular}{lllllll}
\multicolumn{1}{l}{ Model } & Sum of Squares & & Df & Mean Square & F & Sig. \\
\hline & Regression & 44.083 & 2 & 22.042 & 3.144 & .046 \\
1 & Residual & 1044.752 & 149 & 7.012 & & \\
\cline { 2 - 6 } & Total & 1088.836 & 151 & & & \\
\hline
\end{tabular}

Dependent Variable: Green_Bank_BEP

Predictors: (Constant), Env. Train 1, Green Policy1

Bank's Policy, Employee and Daily Operation Related Practices (Green Policy, Environmental Training and Energy Efficient Equipments)

The paper reveals $\mathrm{R}$ square at $0.067,93.3 \%$ of variance of bank's environmental performance is affected by other variables. Of $9.8 \%$ of the variability in the independent variable, majority $(6.7 \%)$ of the variability is explained by bank's policy, employee and daily operation related practices. The level of significance is at $0.016(p<0.05)$. Hence, null hypothesis is rejected.

Table 12

Bank's Policy, Employee and Daily Operation Related Practices

\begin{tabular}{lllll} 
Model & $\mathbf{R}$ & R Square & $\begin{array}{c}\text { Adjusted R } \\
\text { Square }\end{array}$ & Std. Error of the Estimate \\
\hline 1 & .258 & .067 & .048 & 2.62026 \\
\hline
\end{tabular}

Predictors: (Constant), Energy Eff1, Env. Train 1, Green Policy 1

Dependent Variable: Green Bank BEP

Table 13

Analysis of Variance

\begin{tabular}{lllllcc}
\hline & Model & Sum of Squares & Df & Mean Square & F & Sig. \\
\hline & Regression & 72.700 & 3 & 24.233 & 3.530 & .016 \\
1 & Residual & 1016.135 & 148 & 6.866 & & \\
\cline { 2 - 6 } & Total & 1088.836 & 151 & & & \\
\hline
\end{tabular}

Dependent Variable: Green Bank BEP

Predictors: (Constant), Energy Eff1, Env. Train 1, Green Policy1

\section{Conclusion}

The research paper had confirmed statistically significant and positive impact of green banking practices on bank's environmental performance in Nepal explaining $6.8 \%$ of the variation in dependent variable with level of significance at $0.016(p<0.05)$. 
Table 14

Conclusion Summary

\begin{tabular}{lll}
\hline \multicolumn{1}{c}{ Independent Variables } & Regression Result & \multicolumn{1}{c}{ Remarks } \\
\hline 1. Environmental Training & 0.061 & Accepted (Ogee, et al., 2015) \\
2. Energy Efficient Equipment's & 0.009 & Accepted \\
3. Green Policy & 0.008 & Accepted \\
4. Green Loan & 0.224 & Rejected \\
5. Green Project & 0.175 & Rejected \\
\hline
\end{tabular}

Similarly, in simple regression analysis environmental training (0.061), energy efficient equipments (0.009), green policy $(0.008)$ were significant contributor whereas green loan (0.224) and green project (0.175) were not significant with R square of $9.8 \%$. The bank policy related practices (green policy), employee related practices (environmental training) and daily operation related practices (energy efficient equipments) were significant at $0.016(p<0.05)$ whereas customer related practices (green loan and green policy) were not significant predictor of bank's environmental performance. Even though customer related practice seemed to be one of the green banking practices, it does not directly contribute to the environmental performance of the banks as it directly deals with the customers' or general environmental performance.

\section{Implications}

The adoption of green banking strategies will assist the bank to transact with these dangers involved in the business operation. The green banking engage key stakeholders and create awareness about green banking and their impact on the economy, environment and the society (Singh, 2015). It involves banks in carbon credit business, wherefrom services in the area of green development and carbon credit business can be delivered. The products like green credit cards, financial concession (solar, bio-gas, wind and hydro plants) should be provided to customers for using eco-friendly products and services, social clean-up campaigns should be encouraged. Government should provide incentive to first ranked green unit to measure the practices of green banking. Banks should encourage environmentally sustainable technologies that enhance bank's reputation (Biswas, 2011). Both banks and government of Nepal should take initiative to bring awareness among customers regarding green banking (Mehta \& Sharma, 2016).

\section{Acknowledgements}

We would like to express our profound gratitude and deep regards to stakeholders of Master of Business Management (MBM) program of Nepal Commerce Campus, TU for their exemplary guidance, constant encouragement and valuable feedback throughout the duration of the research. Further, we would like to show gratitude towards University Grant Commission, Sanothimi, Bhaktapur for providing funding for the research project. 


\section{References}

American Psychological Association. (2009). Publication Manual of the American

Psychological Association. Washington, USA: APA Service Center.

Aubhi, R. U. (2016). The Evaluation of Green Banking Practices in Bangladesh. Research Journal of Finance and Accounting, 7(6), 94-125. Retrieved July 17, 2018, from http://www.iiste.org/Journals/index.php/RJFA/article/view/30055/30871

Biswas, N. (2011). Sustainable Green Banking Approach:The Need of the Hour. Bsiness Spectrum, 1(1), 32-38. Retrieved January 2018

Gopi, S. (2016). A Study on The Impact of Green Banking in Environmental Protection. International Journal of Advance Research and Innovative Ideas in Education, 1(4), 382-388. Retrieved February 2018, from http://ijariie.com/ AdminUploadPdf/\%E2\%80\%9CA_STUDY_ON_THE_IMPACT_OF_GREEN_BANKING_ IN_ENVIRONMENTAL_PROTECTION\%E2\%80\%9D_WITH_A_SPECIAL_REFERENCE_ TO_SBI_PALAKKAD_DISTRICT_KERALA_1382.pdf

Jayabal, D., \& Soundarya, M. (2016). Green Banking: As Bamks Initiative for Sustainable Development. International Journal of Management, 7(7), 276-280. Retrieved from http://iaeme.com/MasterAdmin/uploadfolder/IJM_07_07_030/IJM_07_07_030. pdf

Jha, D. N., \& Bhome, S. (2013). A study of Green Banking Trends in India. International Monthly Refefrred Journal of Research in Management \& Technology, II, 127132. Retrieved January 4, 2017, from https://www.abhinavjournal.com/images/ Management_\&_Technology/May13/15.pdf

Jovonk, K. (1998). Környezet ès Fejlődès Világbizottság jelentése. Mezőgazdasági Kiado.

Koiry, S., Saha, J. K., Farid, M., Sultana, M., \& Haque, M. (2017). Awareness and Perception of Bank Customers towards Green Banking in Sylhet District of Bangladesh. Asian Journal of Economics, Business and Accounting, 5(2), 1-12. Retrieved January 2018, from http://www.journalrepository.org/media/journals/AJEBA_50/2017/ Dec/Koiry522017AJEBA37811.pdf

Lama, S. (2018). what initiatives are taken by laxmi Bank to Promote green banking practices? (S. K. Joshi, Interviewer) Kathmandu, Kathmandu, Nepal.

Lober, D. (1996). Evaluating the environmental performance of corporations. 8(2), 184205. Retrieved February 2018

Mehta, D., \& Sharma, D. (2016). Customers Persistence for Green Banking in Nepal. Asian Research Consortium, 6(10), 30-44. doi:10.5958/2249-7323.2016.00050.X

Ogee, A., Elis, M., Stone, B. K., Scibilia, B., Pammer, C., \& Steele, C. (2015). What Can You Say When Your P-Value is Greater Than 0.05? (M. B. Editor, Ed.) Pennsylvania, United States: The Minitab Blog. Retrieved October 2, 2018, from http://blog.minitab.com/ blog/understanding-statistics/what-can-you-say-when-your-p-value-is-greaterthan-005

Rajput, D. N., Arora, M. S., \& Khanna, M. A. (2013). An Emperical Study of Impact of Environmental Performance on Financial Performance in Indian Banking Sector. International Journal of Business and Management Invention, 12(9), 19-24. Retrieved June 22, 2018, from http://www.ijbmi.org/papers/Vol(2)9/Version-1/ D0291019024.pdf 
Ritu. (2014). Green Banking: Opportunities and Challenges. International Journal of Informative \& Futuristic Research, 2(1). Retrieved December 30, 2017, from http:// www.ijifr.com/pdfsave/25-09-2014828V2-E1-015.pdf

Salvado, J. A., Castro, G. M., Verde, M. D., \& Lopez, J. E. (2013). In S. Hart (Ed.), Environmental Innovation and Firm Performance: A Natural Resource-Based View (p. 79). United Kingdom: Palgrave Macmillan. Retrieved May 26, 2018, from https://books.google.com.np/books?hl=en\&lr=\&id=yn5fR3kq1RQC\&oi=fnd\&pg=PP 2\&dq=Environmental+Innovation+and+Firm+Performance:+A+Natural+ResourceBased+View+publisher+name\&ots=hDY19ACvGT\&sig=jtYbsrnbBRkXCpcoONjMM JVLFrk\&redir_esc $=y \# v=$ onepage\& $q \&=$ false

Shaumya, K., \& Anton Arulrajah, A. (2017). The Impact of Green Banking Practices on Bank's Environmental Performance: Evidence from Sri Lanka. Journal of Flnance and Bank Management, 5(1), 77-90. Retrieved February 2018, from http://jfbmnet. com/journals/jfbm/Vol_5_No_1_June_2017/7.pdf

Singh, Y. (2015). Environmental Management Through Green Banking: A study of Commercial Banks in India.

Standard Chartered Bank. (n.d.). Retrieved from Standard Chartered Bank Website: https:// www.sc.com/np/sustainability/scb-nepal-activities/en/

Tandon, M. S., \& Setia, M. (2017). Green Banking: An Innovative Initiative for Attaining Sustainable Development. International Journal of science Technology and Management, 6(1), 46-53. Retrieved December 31, 2017, from http://www.ijstm. com/images/short_pdf/1483426770_Page_46-53.pdf 